of his various diseases and their therapy. The onset of gout after many years of steatorrhoea has been described (Marlock \& Rosenberg, 1944) and the possibility that folate deficiency increases circulating uric acid was explored by Zumoff (1953) when investigating a similar case. Folic acid antagonists certainly raise uric acid levels and this supports the suggestion that gout will be aggravated by steatorrhoea. This man's history suggests that he had gout at least 5 years before the anaemia presented. While malabsorption may well have aggravated his gout, it seems unlikely that it initiated the gout in this case. The 3 years' colchicine therapy could be expected to lead to or to aggravate pre-existing mucosal damage in the small bowel, since intestinal function in the rat has been shown to be impaired by this drug (Levin, 1966; Goulston \& Skyrig, 1966). The histological lesions seen in these studies were not, however, identical to those of idiopathic steatorrhoea in man.

Changes in ileal mucosal function in man have been reported on long-term colchicine (Webb et al., 1968), despite the absence of overt gut symptoms. There is one case report of steatorrhoea developing after 10 years of colchicine for gout (Hawkins, 1961). Although it cannot be determined whether or not this man would have developed idiopathic steatorrhoea without colchicine administration, this drug could well have made this worse. It has been shown that the development of neoplastic lesions grafted onto mice can be very significantly inhibited by colchicine therapy (Amoroso, 1935) and improvement of the response of gut adenocarcinoma to radiotherapy in patients on colchicine has been reported (Griem \& Malkinson, 1966). It is possible, therefore, that this man's neoplasm (of a type known to be associated with idiopathic steatorrhoea), may have been inhibited during his time on regular colchicine and that the withdrawal of this drug in the hope that small bowel function would improve, may, in fact, have allowed this neoplasm to proliferate at an increased rate.

\section{Acknowledgments}

We are grateful to Dr W. Brigden who referred this patient to Dr J. T. Wright for investigation, and to Professor I. Doniach for the histological reports.

\section{References}

Amoroso, E.C. (1935) Colchicine and tumour growth. Nature, 135, 266.

Goulston, K.J. \& Skyrig, A. (1966) The effect of colchicine on the absorption of water and electrolytes by rat jejunum. Australian Journal of Experimental Biology and Medical Science, 44, 93.

Griem, M.L. \& Malkinson, F.D. (1966) Modification of radiation response of tissue by colchicine. A clinical evaluation. American Journal of Roentgenology, 97, 1003.

HAwkINS, C.F. (1961) Haematological abnormalities. A Symposium on Metabolic Disorders in Gastrointestinal Disease. Proceedings of the Royal Society of Medicine, 54, 497.

LEVIN, R.J. (1966) Effect of colchicine on intestinal function in the rat. Gut, 7, 250.

LEWIS, J.G. (1962) Gout, steatorrhoea and megaloblastic anaemia. Annals of Rheumatic Disease, 21, 284.

MARLOCK, C.G. \& Rosenberg, E.F. (1944) The co-existence of tophaceous gout and non-tropical sprue. Report of a case. Annals of Internal Medicine, $20,981$.

TALBOT, J.H. (1959) Gout and blood dyscrasias. Medicine, 38, 173.

Webb, D.J., Chados, R.B., Mahar, C.Q. \& Faloon, W.F. (1968) Mechanism of vitamin $B_{12}$ malabsorption in patients receiving colchicine. New England Journal of Medicine, 279, 845.

Zumoff, B. (1953) Possible relationship of folic acid to uric acid metabolism as exemplified by a case of non-tropical spruce. American Journal of Medical Sciences, 225, 674.

\title{
Monozygous twins with hypothyroidism and diabetes mellitus
}

\author{
I. MitChelL \\ M.B., M.R.C.P., D.C.H. \\ Western General Hospital, Edinburgh
}

\section{Summary}

Monozygous twins with diabetes mellitus and autoimmune hypothyroidism are described. The onset of the hypothyroidism was simultaneous, but one twin had had insulin-dependent diabetes mellitus for 9 years while the other twin developed insulin-independent diabetes concurrently with the hypothyroidism. Two

Correspondence: Dr I. Mitchell, Registrar, Paediatric Department, Western General Hospital, Crewe Road, Edinburgh 4. 
Zaino \& Guerra, 1964; Beierwalter, 1965; Hennen \& Dodinval, 1965; Diamond \& Joffe, 1966; Hoffman, 1966; Foley et al., 1968; Kessler, 1968), although not with coincident diabetes mellitus. Primary hypothyroidism is thought to be an autoimmune disease, and to be associated with other autoimmune disorders such as Addison's disease, pernicious anaemia and rheumatoid arthritis. The association of Addison's disease and diabetes mellitus is well recognized (Turner \& Bloom, 1968; Ghavib \& Gastimeau, 1969) and there is good evidence that diabetes mellitus and hypothyroidism may occur in the same patient (Landing et al., 1963; Hecht \& Gershkert, 1968; Bridgman, 1971). Moreover, antibodies to thyroid cytoplasm are present more frequently in insulin-dependent diabetics than in non-insulin-dependent diabetics or in the normal population (Irvine et al., 1970; Whittingshaw et al., 1971). These associations all suggest that diabetes mellitus may sometimes also be an autoimmune disease.

The present study describes identical twins who developed hypothyroidism simultaneously; one had diabetes mellitus for some years, but the other developed this condition at the same time as hypothyroidism.

\section{The twins}

Figure 1 shows the family tree of the twin sisters described.

\section{Patient 1 ( $\mathrm{II}_{3}$, Fig. 1) age 63}

This patient consulted her general practitioner because her urine had been red. Chemical and microscopical examination of the urine confirmed haematuria, but also showed glycosuria and she was then referred to hospital. More detailed history revealed that she had been vaguely unwell for 2 years, had had lassitude for a few months and for some weeks she had been so lethargic that she had not left the house. She had noticed swellings under her eyes, and her voice had become indistinct and husky. She had no urinary symptoms and had noticed no change in weight, which was $54.5 \mathrm{~kg}$ (ideal weight for height and age $57 \mathrm{~kg}$; criteria of Metropolitan Life Insurance Company, quoted in Davidson \& MacLeod, 1971).

She was obviously myxoedematous, with a hoarse voice, dry skin, pads of myxoedematous tissue under both eyes, coarse hair and 'erythema ab igne'. Ankle jerks were pendular, but cardiovascular and respiratory systems were normal apart from sinus bradycardia (rate 60/min).

\section{Patient 2 ( $\mathrm{II}_{4}$, Fig. 1)}

This patient was investigated because of her sister's illness. She had been lethargic for 18 months and had given up a part-time job 4 months before because of general weakness. Her thinking was slow, she had developed cold intolerance and had become dyspnoeic on moderate exertion. There had also been a small increase in weight.

She had been known to have diabetes mellitus for 9 years. The initial presentation (age 54) was with a 3 month history of polyuria, polydipsia, weight loss and pruritus vulvae, and a $50 \mathrm{~g}$ oral glucose tolerance test (Table 1), confirmed diabetes mellitus. She was treated with oral hypoglycaemic drugs, but relapse occurred after 1 month, and since then insulin had been required for control. At the time of admission she was taking 28 units of Lente

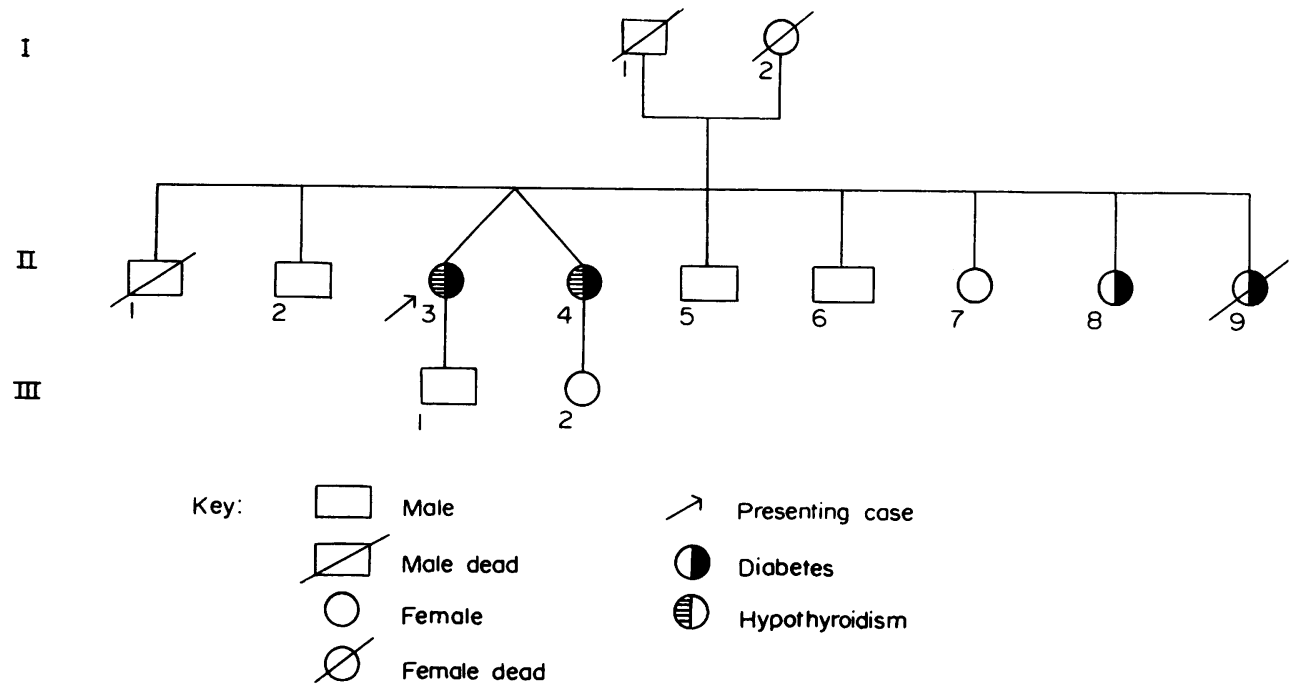

FIG. 1. Diagram of family tree. 
TABLE 1. Results of investigations

\begin{tabular}{|c|c|c|}
\hline & \multicolumn{2}{|c|}{ Patient } \\
\hline & 1 & 2 \\
\hline Haeomoglobin $(\mathrm{g} / 100 \mathrm{ml})$ & $10 \cdot 5$ & $12 \cdot 6$ \\
\hline Chest X-ray & $\begin{array}{c}\text { Slight } \\
\text { cardiomegaly }\end{array}$ & Normal \\
\hline Electrocardiograph & $\begin{array}{l}\text { Sinus } \\
\text { bradycardia }\end{array}$ & $\begin{array}{c}\text { Sinus } \\
\text { bradycardia }\end{array}$ \\
\hline \multicolumn{3}{|l|}{ Protein-bound iodine (PBI) } \\
\hline$\mu \mathrm{g} / 100 \mathrm{ml}$ & $1 \cdot 0$ & $1 \cdot 8$ \\
\hline$T_{3}$ resin test ${ }^{*}$ & $0 \cdot 79$ & 0.84 \\
\hline Serum cholesterol $(\mathrm{mg} / 100 \mathrm{ml})$ & 400 & 344 \\
\hline $\begin{array}{l}\text { 48-hr uptake of }{ }^{131} \text { I } \\
\text { 4-hr uptake of }{ }^{132} \text { I after three }\end{array}$ & $8 \%$ & - \\
\hline daily injections of TSH† & - & $9 \%$ \\
\hline Fasting blood glucose $(\mathrm{mg} / 100 \mathrm{ml}) \ddagger$ & 112 & 186 \\
\hline \multicolumn{3}{|l|}{$\begin{array}{l}\text { Blood glucose after } 50 \mathrm{~g} \text { glucose } \\
\text { orally (hr): }\end{array}$} \\
\hline$\frac{1}{2}$ & 140 & 316 \\
\hline 1 & 206 & 400 \\
\hline $1 \frac{1}{2}$ & 245 & 424 \\
\hline 2 & 235 & 372 \\
\hline $2 \frac{1}{2}$ & 200 & 304 \\
\hline
\end{tabular}

* Normal range 0.08-1.02.

$\dagger$ Thyroid stimulating hormone.

$¥$ Blood glucose figures for patient 1 in 1971 , patient 2 in 1962 .

insulin daily. She had the typical appearance of myxoedema (Fig. 2), but no other abnormality, and was slightly overweight (weight $64.5 \mathrm{~kg}$, compared with an ideal weight of $57 \mathrm{~kg}$; criteria of Metropolitan Life Insurance Company, quoted in Davidson \& McLeod, 1971).

Investigations. Results are shown in Table 1 and the thyroid antibody studies in Table 2 . The thyroid function tests confirmed hypothyroidism in each patient, and both glucose tolerance tests were diabetic, although the fasting glucose in Patient 1 was not markedly raised. The finding of a strongly positive immunofluorescence test for thyroid cytoplasmic antibody and the high titre of antibody to thyroglobulin justified a diagnosis of Hashimoto's disease. Examination of chromosomes in cultured lymphocytes from peripheral blood was normal.

Evidence for monozygosity. They were of similar appearance prior to the onset of hypothyroidism. The blood groups and enzyme groupings (Table 3 ) were identical, and thus there was a high probability that they are identical twins.

Progress. Both patients were given replacement therapy (thyroxine) in standard dosage and slowly lost the features of myxoedema. Patient 1 was treated with a 1200 calorie diabetic diet, and on this regime the diabetes was controlled for a short time, but insulin was subsequently necessary. She also had an intercurrent urinary infection, which responded to nalidixic acid. There was no other demonstrable abnormality of the urinary tract. The other twin required a small temporary increase in her dosage of insulin after starting thyroxine, but later her insulin requirements fell to their previous level.

\section{Other members of the family}

Parents ( $I_{1}$ and $I_{2}$, Fig. 1)

Both parents were dead, aged 73 (mother) and 70 (father), but there was no history of thyroid disease or diabetes mellitus. They were not related.

TABLE 2. Thyro-gastric antibodies

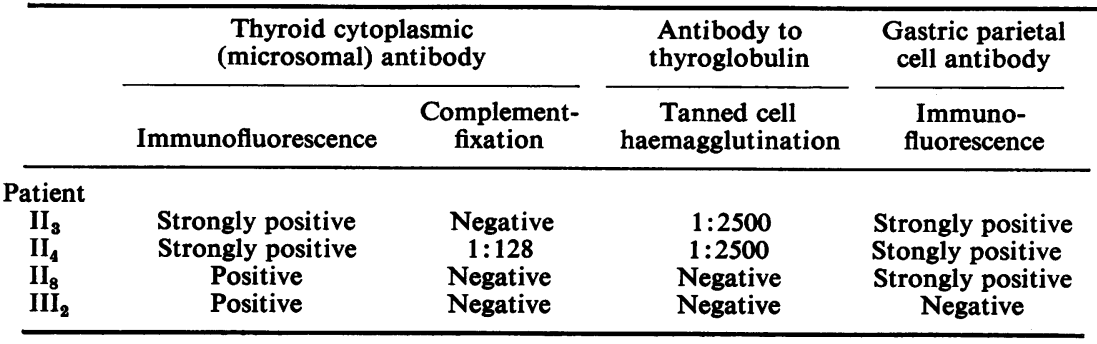




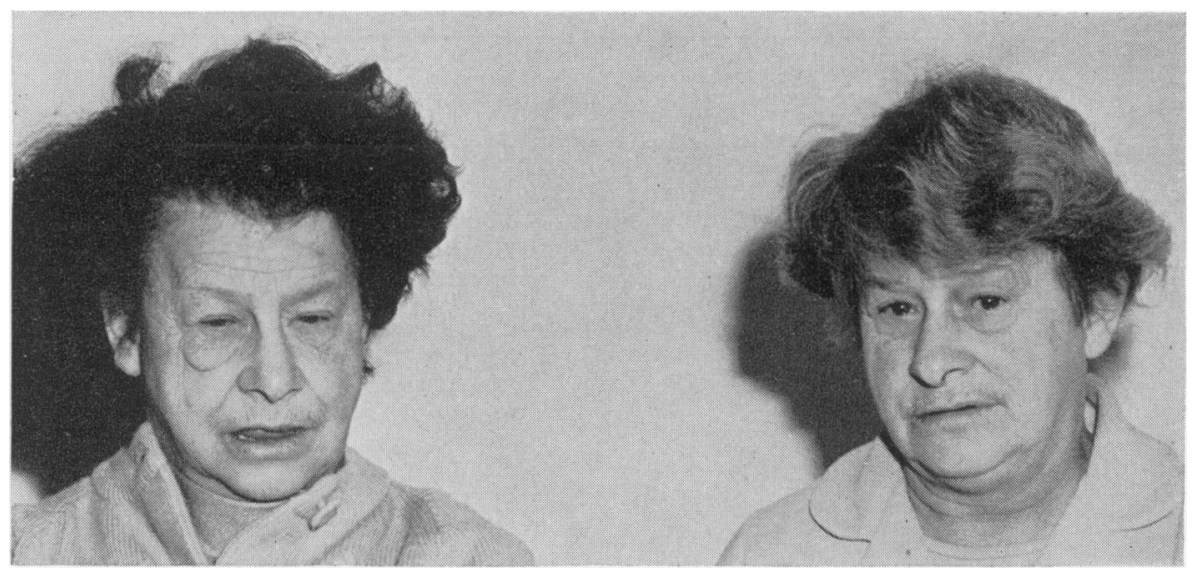

FIg. 2. Picture of the twins. Patient 1 on left-hand side; patient 2 on right-hand side.

\section{Brothers}

One brother died $\left(\mathrm{II}_{1}\right.$, Fig. 1) some years ago, but there was no evidence he was hypothyroid or diabetic. Three brothers $\left(\mathrm{II}_{2,5,6}\right.$, Fig. 1) were still alive. They declined medical examination, but according to their family doctor they were healthy.

\section{Sisters}

It was not possible to examine one sister $\left(_{I_{7}}\right.$, Fig. 1), but as far as is known she does not have hypothyroidism or diabetes mellitus.

TABLE 3. Evidence for monozygosity

\begin{tabular}{lc}
\hline & $\begin{array}{c}\text { O Rh positive } \\
\text { (probable genotype CDE/cDE) }\end{array}$ \\
Blood groups & $\mathbf{M}+\mathbf{N}-\mathbf{P}+++\mathbf{K}-$ LeA + FyA + \\
\hline Enzyme groups & $2-2$ \\
Haptoglobins & $\mathbf{C}$ \\
Transferase & $\mathbf{A}$ \\
Acid phosphatase & $2-1$ \\
Phosphoglucomutase & 1 \\
Alkaline phosphatase & 1111 \\
Pepsidase & $\mathbf{M}$ \\
$\alpha_{1}$-antitrypsin & \\
\hline
\end{tabular}

The remaining living sister $\left(\mathrm{II}_{8}\right.$, Fig. 1), age 54, has had diabetes mellitus since 1957 . She presented then with a 4 week history of polydipsia and polyuria, and glucose tolerance test confirmed diabetes mellitus (fasting blood sugar $150 \mathrm{mg} / 100 \mathrm{ml}$, and $300 \mathrm{mg} / 100 \mathrm{ml} 90 \mathrm{~min}$ after $50 \mathrm{~g}$ oral glucose). She was treated with insulin and currently remains well controlled. When age 20 she developed a goitre, was nervous and agitated, but had no tachycardia (pulse rate $66 / \mathrm{min}$ ). She had a normal BMR ( $+7 \%$, Benedict-Roth). The symptoms settled with no specific treatment. Chest X-ray was abnormal (first noted in 1957) and after cardiac catheterization and angiocardiography it was concluded that the right pulmonary veins entered the inferior vena cava. There has never been any evidence of cardiac decompensation.

When seen by us, she was clinically euthyroid and there was no abnormality on examination apart from a small goitre.

Investigations. PBI $6.8 \mu \mathrm{g} / 100 \mathrm{ml}, \mathrm{Hb} 14.6 \%$ $\mathrm{g} / 100 \mathrm{ml}$, postprandial blood glucose $298 \mathrm{mg} / 100 \mathrm{ml}$. Thyroid antibody studies are shown in Table 2 and were suggestive, but not conclusive, of lymphadenoid goitre.

A third sister ( $\mathrm{II}_{9}$, Fig. 1) died age 43 , but had been diabetic from the age of 30 and was controlled with insulin. The cause of death was an adenocarcinoma of the colon with metastases. There is no information on her thyroid status.

\section{Children}

Patient 1 has one son (III, Fig. 1) who refused to attend for examination as he 'felt perfectly well'.

Patient 2 has one daughter (III ${ }_{2}$, Fig. 1) who is aged 36. She was overweight (weight $84.8 \mathrm{~kg}$, standard for height and age $57.6 \mathrm{~kg}$; criteria of Metropolitan Life Insurance Company, quoted in Davidson \& McLeod, 1971), but had no other abnormality on examination and there was no goitre. There was no previous history of note, but she had three children whose birth weights were $2.72 \mathrm{~kg}, 4.54 \mathrm{~kg}$ and $3.99 \mathrm{~kg}$.

Investigations. PBI $5.3 \mu \mathrm{g} / 100 \mathrm{ml}$, Hb 14.6 $\mathrm{g} / 100 \mathrm{ml}$, and steroid-augmented oral glucose tolerance test was normal. Thyroid antibody studies are shown in Table 2, and although positive immunofluorescence tests for thyroid cytoplasmic antibody are found in normal people, this is unusual. 


\section{Discussion}

Hashimoto's thyroiditis (lymphadenoid goitre) is now thought to be part of a group of diseases which includes thyrotoxicosis, simple goitre and primary hypothyroidism (myxoedema), depending on the stage of the pathological process. Fibrosis with resultant hypothyroidism is the end stage, and although all forms of the disease may be seen at different times in the same individual, this is unusual. Hypothyroidism occurs in relatives of patients more often than by chance (Hoffman, 1966; Dunning, 1969) and also different forms of the basic disease have been noted in members of a family by Jayson et al. (1967) and Parieier, Goldberg \& Vidal (1971).

These diseases are thought to belong to the autoimmune group of diseases, and antibodies to thyroglobulin and thyroid cytoplasm are present in lymphadenoid goitre and primary myxoedema, and an abnormal globulin (LATS) is found in primary thyrotoxicosis. Hypothyroidism is much more common in women and is also seen in association with other autoimmune diseases (Jayson et al., 1967; Gastimeau \& Arnold, 1963). In addition, Irvine, Stewart \& Scarth (1967) showed that the immunological abnormalities of hypothyroidism are found in patients with autoimmune diseases who do not have a goitre and are euthyroid as well as those with clinical evidence of thyroid disease. The relationship of antibodies to thyroglobulin and thyroid cytoplasm to the aetiology of hypothyroidism is complex, and Irvine (1964) demonstrated that the antibodies did not seem to cause direct damage, as was once thought to be the case. It may well be that there is a genetically determined defect in immunological tolerance in the organ-specific autoimmune diseases, and although the mode of inheritance is complex, the genetic theory of aetiology is supported by finding thyroid disease in relatives of patients with primary hypothyroidism and also the increased incidence of thyroid antibodies in otherwise normal relatives (Hall, Owen \& Smart, 1960; Doniach \& Roitt, 1966).

Previous reports of primary hypothyroidism in identical twins are supportive evidence for a genetic basis. The present study adds to this evidence as these twins were monozygous, hypothyroid and had serological findings compatible with Hashimoto's disease. Thyroid antibodies were not strongly positive in patient $\mathrm{II}_{8}$ (Fig. 1), but she had had a goitre some years previously and possibly the serological abnormalities had not fully developed (Whittingshaw et al., 1971). In this case, biopsy of the thyroid gland might have been useful in confirming a diagnosis of Hashimoto's disease. Unfortunately, diseases which are concordant in twins are much more likely to be reported than disease which are discordant. Although there have been no reports of twins discordant for autoimmune hypothyroidism, Harvald \& Hauge (1956) reported this in thyrotoxicosis. In their survey of twins with goitre Greig et al. (1967) disclosed no pairs with hypothyroidism, although a number of monozygous twins were discordant for thyroid antibodies. These patients were young and healthy, the antibody titres low and the relevance of this finding to disease was not clear. Moncrieff \& McArthur (1968) reported twins discordant for hypothyroidism, but all these patients were infants and young children; antibodies to the thyroid gland were only performed in one pair and were negative. Although autiommune thyroid disease is recognized in older children (Hahn, Hayles \& Woolner, 1965) it must be very rare in infants. The patient of von Harnoch (cited by Moncrieff \& McArthur, 1968) was born to a mother who was thyrotoxic when pregnant, but the relationship of this to the child's hypothyroidism was obscure.

It is known that autoimmune hypothyroidism occurs in association with some disorders of the X chromosome (Fialkow, 1967; Engel, Northcutt \& Bunting, 1969; McHardy-Young, Doniach \& Polari, 1970) as does diabetes mellitus (Forbes \& Engel, 1963) and it has been suggested that alterations and deletions to the $\mathrm{X}$ chromosome may occur in old age and predispose the patient to hypothyroidism. This would certainly explain the predilection of the disease for elderly women. However, the chromosomes of the twins reported here were normal.

The twins described here were both insulindependent diabetics. Gottlieb \& Root (1968) showed that there is a high concordance for diabetes in identical twins, especially if the proband is more than 40 years old, but the concordance is not $100 \%$. It has been suggested that prolonged follow-up will disclose $100 \%$ concordance but Pyke et al. (1970) failed to demonstrate this. Like hypothyroidism the exact mode of inheritance of diabetes mellitus is not known, and although it frequently occurs in more than one member of a family, insulin-dependent and insulin-independent diabetes may occur in different members of the same family. Patient $\mathrm{III}_{2}$, Fig. 1, whose mother and three aunts are diabetic and who had one child weighing more than $4.5 \mathrm{~kg}$, was overweight and may be regarded as a potential diabetic (FitzGerald, Malins \& O'Sullivan, 1961; FitzGerald \& Keen, 1964). Also, Irvine (1967) has pointed out that antithyroid antibodies present in a low titre may become more abnormal.

The association of thyroid disease, anti-thyroid antibodies and diabetes mellitus in the monozygous twins here described, together with the sister $\left(\mathrm{II}_{8}\right.$, Fig. 1) who had diabetes mellitus and a significant titre of anti-thyroid antibodies strengthens the 
suggestion of Landing et al. (1963), Irvine et al. (1970) and Whittingshaw et al. (1971) that autoimmunity may be a factor in the aetiology of diabetes mellitus.

\section{Acknowledgments}

We would like to thank Dr W. Price, Department of Cytogenetics, Western General Hospital, Edinburgh, for carrying out the chromosome analysis and the Galton Laboratory, London, who performed the blood and enzyme groupings. We also thank Dr W. J. Irvine, Royal Infirmary, Edinburgh, for performing the immunological studies.

\section{References}

Austoni, M., Callegari, F. \& Borimi, P. (1964) Autoimmune thyroiditis (Hashimoto's disease) in uniovular twins. Folia allergologica, 11, 83.

Beierwalter, W.H. (1965) Thyroiditis. Annals of the New York Academy of Sciences, 124, 586.

Bridgman, J.F. (1971) Diabetes mellitus and hypothyroidism. Postgraduate Medical Journal, 47, 781.

Davidson, Sir Stanley \& MacLeod, J. (1971) The Principles and Practice of Medicine, 10th edn, p. 1161. Churchill Livingstone, Edinburgh and London.

Diamond, M.T. \& Joffe, B. (1966) Monozygotic twins with chronic lymphocytic thyroiditis (Hashimoto's disease). Journal of the American Medical Association, 198, 202.

DoniaCH, D. \& RoITT, I.M. (1966) Family studies on gastric autoimmunity. Proceedings of the Royal Society of Medicine, 59, 691 .

DUNNING, E.J. (1969) Struma lyphomatosa: a report of three cases in one family. Journal of Clinical Endocrinology and Metabolism, 19, 1121.

ENGel, E. NorthCutt, R.C. \& Bunting, K.W. (1969) Diabetes and hypothyroidism in a patient with a long arm X-iso-chromosome. Journal of Clinical Endocrinology and Metabolism, 29, 130.

Fialkow, P. (1967) Autoantibodies and chromosomal aberrations. Lancet, i, 1106.

FitzGerald, M.G. \& Keen, H. (1964) Diagnostic classification of diabetes. Lancet, $\mathbf{i}, 1325$.

FitzGerald, M.G., Malins, J.M. \& O'Sullivan, D.J. (1961) Prevalence of diabetes in woman 13 years after bearing big baby. Lancet, i, 1250 .

Foley, T.P. JR., Schubert, W.W., Maxwell, R.T. \& McAdams, A.J. (1968) Chronic lymphocytic thyroiditis and juvenile myxoedema in uniovular twins. Journal of Paediatrics, 72, 201.

Forbes, A.P. \& ENGEL, E. (1963) The high incidence of diabetes mellitus in forty-one patients with gonadal dysgenesis and their close relatives. Metabolism: Clinical and Experimental, 12, 428.

Gastimeau, C.F. \& ARNOLD, J.W. (1965) Thyroid disorders in Addison's disease: myxoedema and goitre. Proceedings of the Staff Meetings of the Mayo Clinic, 38, 323.

GhaviB, H. \& GastimeaU, C.F. (1969) Coexisting Addison's disease and diabetes mellitus; report of twenty-four cases with review of literature. Proceedings of the Staff Meetings of the Mayo Clinic, 44, 217.

GotTlieb, M.S. \& Root, H.F. (1968) Diabetes mellitus in twins. Diabetes, 17, 693.

Greig, W.R., Boyle, J.A., Duncan, A., Nicol, J., Gray, M.J.B., Buchanan, W.W. \& McGirR, E.M. (1967)
Genetic and non-genetic factors in simple goitre formation: evidence from a twin study. Quarterly Journal of Medicine, 36, 175.

Hahn, H.B., Hayles, A.B. \& Woolner, L.B. (1965) Lymphocytic thyroiditis in children. Paediatrics, 66, 73.

Hall, R., OWen, S.G. \& Smart, G.A. (1960) Evidence for genetic predisposition to formation of thyroid antibodies. Lancet, ii, 187.

HaRvald, B. \& Hauge, M. (1956) Quoted by Jayson et al. (1967). Danish Medical Bulletin, 3, 150.

Hecht, A. \& Gershkert, H. (1968) Diabetes mellitus and primary hypothyroidism. Metabolism, 17, 108.

HenNen, G. \& Dodinval, P. (1965) Simultaneous appearance of a primary thyroid insufficiency in a pair of uniovular twins. Acta endocrinologica, 49, 487.

Hoffman E. (1966) Hashimoto's thyroiditis (struma lymphomatosa). Case report of a mother and three daughters, two of whom are monozygous twins. Archives of Surgery, 92, 865.

IRviNE, W.J. (1964) Thyroid autoimmunity as a disorder of immunological tolerance. Quarterly Journal of Experimental Physiology, 49, 324.

IRVINE, W.J. (1967) Autoimmunity and endocrine disorders. Practitioner, 199, 180.

Irvine, W.J., Clarke, B.F., Scarth, L., Cullen, D.R. \& DunCAN, L.J.P. (1970) Thyroid and gastric autoimmunity in patients with diabetes mellitus. Lancet, ii, 163.

Irvine, W.J., MacGregor, A.G., Stuart, A.E. \& Hall, G.H. (1961) Hashimoto's disease in uniovular twins. Lancet, ii, 850.

Irvine, W.J., Stewart, A.H. \& Scarth, L. (1967) A clinical and immunological study of adrenocortical insufficiency (Addison's disease). Clinical and Experimental Immunology, 2,31 .

Jayson, M.I.V., Doniach, D., Benhamau-GlynN, N., RoITT, I.M. \& ElKabin, D.J. (1967) Thyrotoxicosis and Hashimoto's goitre in a pair of monozygous twins. Lancet, ii, 15.

KESSLER, A. (1968) Bronchial asthma, hypothyroidism (myxoedema) and glaucoma in monozygous twins. Dapim Reffuim, 27, 314.

Landing, B.H., Pettit, M.D., Wiens, R.L., Knowles, H. \& Guest, G.N. (1963) Antithyroid antibody and chronic thyroiditis in diabetes. Journal of Clinical Endocrinology and Metabolism, 23, 119.

Mchardy-Young, S., Doniach, D. \& Polani, P.E. (1970) Thyroid function in Turner's syndrome and allied conditions. Lancet, ii, 1151

MoncriefF, M.W. \& McArthur, R.G. (1968) Hypothyroidism in one of monozygotic twins. Postgraduate Medical Journal, 44, 423.

Parieier, H., Goldberg, V. \& Vidal, E.R. (1971) Family group with autoimmune thyroid disease. Journal of Clinical Endocrinology and Metabolism, 32, 680.

Pyke, D.A., Cassar, J., Todd, J. \& TAylor, K.W. (1970) Glucose tolerance and serum insulin in identical twins of diabetics. British Medical Journal, 4, 649.

Turner, R.C. \& Bloom, A. (1968) Diabetes mellitus, Addison's disease and pernicious anaemia. Postgradua :e Medical Journal, 44, 555.

Whittingshaw, S., Matthews, J.D., Mackay, I.R., Stocks A.E., Ungar, B. \& MARTIN, F.I.R. (1971) Diabetes mellitus, autoimmunity and ageing. Lancet, i, 763.

Zaino, E.C. \& Guerra, W. (1964) Hashimoto's disease (struma lymphomatosa) in identical twins. Archives of Internal Medicine, 113, 70. 